\title{
A Rare Case of Carbuncle at the Right Lumbar Region: A Case Report
}

\author{
Rajalakshmi Rajaraman ${ }^{1}$, K Renuka ${ }^{2}$
}

\begin{abstract}
A 77-year-old client got admitted to Mahatma Gandhi Medical College and Research Institute with the signs and symptoms of swelling in the right-side lower back and pain with discharge. He has been diagnosed to have carbuncle-right lumbar disorder. Carbuncle is a rare condition that may be misdiagnosed clinically, because of the atypical nature of the disease. Hence, a clear clinical picture is necessary for the identification and correct diagnosis of the case.
\end{abstract}

Keywords: Abscess, Carbuncle, Saucerization, Staphylococcus skin infection.

Pondicherry Journal of Nursing (2020): 10.5005/jp-journals-10084-12148

\section{INTRODUCTION}

An abscess or furuncle appears beneath the skin in the hair duct which is caused mostly by the Staphylococcus aureus bacterial infections (red colored, bulgy, aches, irritation, and discomfort with pus collection which later leaves a scar). ${ }^{1-5}$ It is otherwise called as a staph skin infection. The study findings proved that the typical site of carbuncle was neck (40\%) followed by the back (26.67\%). Around $40 \%$ of the clients with the symptoms of more than 2 weeks duration. ${ }^{6}$ About $20 \%$ of the clients feel the necessity for repeat surgery. Mostly, it occurs as a single, to occur on a hairy area of the body such as the back or nape of the neck but a carbuncle also can develop in other areas of the body such as the buttocks, thighs, groin, and armpits. ${ }^{3}$ The detailed content of the case report was given below.

\section{Case Description}

\section{Case History and Physical Examination}

A 77-year-old client got admitted in Mahatma Gandhi Medical College and Research Institute with the signs and symptoms of swelling in the right-side lower back for 5 days which was insidious in onset, progressing gradually to attain the present size. The pain was pricking type, non-radiating, aggravating on movement, and relieves on resting in a prone position, foul-smelling purulent discharge from the swelling for past 3 days. There is no history of fever, cough, constipation, or loose stools. There was a significant past medical history of mucoepidermoid parotid gland cancer for which he underwent parotidectomy surgery 6 months ago. He also has facial palsy with features like drooping of the eyelid in the right side, drooling of saliva in the right side, and the loss of expression on the right cheek. He has been diagnosed to have carbuncle-right lumbar disorder. The physical examination of the lower back found swelling $10 \times 8 \mathrm{~cm}$ with irregular-edged vague mass in the lower back, present with pus, skin discoloration over swelling, and the presence of skin erythema.

\section{Investigations}

\section{USG-Swelling on the Back Findings}

An ill-defined collection measuring $1.9 \times 1.5 \times 1.3 \mathrm{~cm}$ (volume $2 \mathrm{cc}$ ) with marked surrounding inflammatory changes and peripheral

\begin{tabular}{|c|c|c|c|c|}
\hline $\begin{array}{l}\text { 1,2 Department of } \\
\text { Nursing College, } \mathrm{Sr}\end{array}$ & $\begin{array}{l}\text { Oommunit } \\
\text { Balaji Vidy }\end{array}$ & $\begin{array}{l}\text { Healt } \\
\text { eeth, } \mathrm{F}\end{array}$ & $\begin{array}{l}\text { ursing, } \\
\text { cherry, I }\end{array}$ & turba Gandhi \\
\hline $\begin{array}{l}\text { Corresponding A } \\
\text { Community Healt } \\
\text { Balaji Vidyapeeth, } \\
\text { rajalakshmielayara }\end{array}$ & $\begin{array}{l}\text { thor: Raj } \\
\text { Nursing, } \\
\text { ducherry, } \\
\text { @gmail.co }\end{array}$ & $\begin{array}{l}\text { kshmi } \\
\text { sturba } \\
\text { dia, } \mathrm{Pl}\end{array}$ & $\begin{array}{l}\text { araman } \\
\text { dhi Nu } \\
+916\end{array}$ & $\begin{array}{l}\text { epartment of } \\
\text { g College, Sri } \\
61238 \text {, e-mail: }\end{array}$ \\
\hline $\begin{array}{l}\text { How to cite this } \\
\text { Carbuncle at the } \\
2020 ; 13(2): 37-38 \text {. }\end{array}$ & $\begin{array}{l}\text { ticle: Raj } \\
\text { ght Lumb }\end{array}$ & $\begin{array}{r}\text { kshmi } \\
\text { Regio }\end{array}$ & $\begin{array}{l}\text { enuka } \\
\text { Case R }\end{array}$ & $\begin{array}{l}\text { Rare Case of } \\
\text { rt. Pon J Nurs }\end{array}$ \\
\hline Source of support & & & & \\
\hline Conflict of interest & None & & & \\
\hline $\begin{array}{l}\text { vascularity is not } \\
\text { swelling. Mobile, }\end{array}$ & $\begin{array}{l}d \text { at the } r \\
\text { ick echor }\end{array}$ & $\begin{array}{l}\text { it lum } \\
\text { hic cor }\end{array}$ & $\begin{array}{l}\text { region } \\
\text { ts are n }\end{array}$ & $\begin{array}{l}\text { he site of the } \\
\text { d. }\end{array}$ \\
\hline Course in the $\mathrm{F}$ & spital & & & \\
\hline $\begin{array}{l}\text { He was admitte } \\
\text { underwent sauc } \\
21,2020 \text {, under } 9 \\
\text { postoperatively. } \\
\text { dressing was do } \\
\text { below-mentione }\end{array}$ & $\begin{array}{l}\text { to the } \\
\text { ization, } \\
\text { neral ane } \\
\text { he cultu } \\
\text { and dis } \\
\text { drugs: }\end{array}$ & $\begin{array}{l}\text { spital } \\
\text { cision } \\
\text { hesia. } \\
\text { was } \\
\text { largec }\end{array}$ & $\begin{array}{l}\text { Januar } \\
\text { d drair } \\
\text { patier } \\
\text { le and } \\
\text { Januar }\end{array}$ & $\begin{array}{l}0,2020 \text {, and } \\
\text { on January } \\
\text { covered well } \\
\text { cadexomer } \\
4,2020 \text {, with }\end{array}$ \\
\hline T. Paracetamol & $650 \mathrm{mg}$ & $\mathrm{p} / \mathrm{o}$ & $1-0-1$ & $\begin{array}{l}2 \text { days then } \\
\text { sOS }\end{array}$ \\
\hline T. Pantoprazole & $40 \mathrm{mg}$ & $\mathrm{p} / \mathrm{o}$ & $1-0-1$ & 5 days \\
\hline T. Rutoheal & $1 \mathrm{Tab}$ & $\mathrm{p} / \mathrm{o}$ & $1-0-1$ & 5 days \\
\hline Fourts B & $1 \mathrm{Tab}$ & $\mathrm{p} / \mathrm{o}$ & $0-1-0$ & 15 days \\
\hline $\begin{array}{l}\text { Lacrigel ointment } \\
\text { intraocular }\end{array}$ & & & $0-0-1$ & \\
\hline $\begin{array}{l}\text { Lubrex eye drop } \\
\text { intraocular }\end{array}$ & & & $1-1-1$ & \\
\hline
\end{tabular}

\section{Discussion}

The management of clients presenting with carbuncle depends on the clinical manifestations. Majority of clients will recover with conservative treatment (requiring analgesia, anti-inflammatory and antibiotic). However, the most common surgical approaches are saucerization, and incision and drainage (I\&D). ${ }^{7-11}$ 


\section{Conclusion}

Boils and abscesses are generally thought to be more common in males, although there are some published data to support this. ${ }^{12}$

\section{Declaration of Patient Consent}

The authors certify that they have obtained all appropriate patient consent forms. In the form, the patient(s) has given his consent for his clinical information to be reported in the journal. The clients understand that their names and initials will not be published and due efforts will be made to conceal their identity, but anonymity cannot be guaranteed.

\section{References}

1. Carbuncle; Available from http://en.wikipedia.org/wiki/Carbuncle.

2. Tripathy BB. Landmarks in the history of diabetes. In: RSSDI textbook of diabetes mellitus. 2nd ed., 2008. pp. 7-45.
3. https://www.healthline.com/health/carbuncle.

4. https://www.webmd.com/skin-problems-and treatments/guide/ carbuncles-causes-treatments\#1.

5. https://medlineplus.gov/ency/article/000825.htm.

6. Jain AKC, Nisha ST, Viswanath S. Carbuncle in diabetics-our experience. Sch J App Med Sci 2013;1(5):493-495.

7. Mohammed JA, Al-Ajmi S, Al-Rasheed AA. Surgical management of post carbuncle soft tissue defect in diabetic patients. Middle East Journal of Family Medicine 2007;5(4).

8. Chelliah G, Hamzah AA, Ahmed MZ, Ahmad RS. Carbuncle of the chin: A case report and literature review. Libyan J Surg 2013;2: 839571.

9. Bhat SM. SRB's manual of surgery. 3rd ed., India: Jaypee Brothers, Medical Publishers; 2009.

10. Das S. A concise textbook of surgery. 3rd ed., India 2001.

11. Franklin $\mathrm{RH}$. The treatment of carbuncles. Postgr Med J 1937;13(142):284-287. DOI: 10.1136/pgmj.13.142.284.

12. National Institute of Health and Care Excellence Boils, carbuncles and staphylococcal carriage. http://cks.nice.org.uk/boils-carbuncles-andstaphylococcal carriage\#!scenario:1. 